Беляева Елена Львовна (Москва). Кандидат технических наук, советник РААСН, член-корреспондент РАЕН. Директор 000 «Институт геобиосферных исследований» (113105, Москва, Варшавское шоссе, 8. 000 «ИГБИ»). Эл.почта: igbi@уandex.ru.

Беляев Александр Юрьевич (Москва). Кандидат технических наук. Начальник Управления инженерной службы Комитета по архитектуре и градостроительству города Москвы (125047, Москва, Триумфальная площадь, 1. Москомархитектура).

Belyaeva Elena L. (Moscow). Candidate of Technical Sciences, Advisor of RAACS, Corresponding Member of the Russian Academy of Natural Sciences. Director of the 000 "Institute of Geobiosphere Research" (8 Varshavskoe Highway, Moscow, 113105. IGBI). E-mail: igbi@yandex.ru.

Belyaev Alexander Y. (Moscow). Candidate of Technical Sciences. Head of the Department of Engineering Service of the Committee for Architecture and Urban Planning of Moscow (1 Triumfalnaya Square, Moscow, 125047. Moskomarkhitektura).

( Беляева Е.Л., Беляев А.Ю., 2021. Academia. Архитектура и строительство, № 4, стр. 99-109.

\title{
$0 б$ истории городского благоустройства и инженерных сетей Москвы. Часть 2. Благоустройство и инженерные сети XVIII - начала XX веков*)
}

\author{
Е.Л.Беляева, ИГБИ, Москва \\ А.Ю.Беляев, Москомархитектуры, Москва
}

XVIII век. Камер-Коллежский вал и обустройство новой границы Москвы. Землеустройство и межевание, как основа планировочных преобразований. Генплан архитектора Кожина, «Каменный приказ». Болотов и опыт садово-паркового искусства пригородов

По окончании «смутного времени» всё ещё существовала угроза продолжения «Северной войны», и в 1700-1721 годы вокруг Кремля и Белого города для защиты от нападения шведов строились дополнительные укрепления. В начале XVIII века Москва становится главным торгом государства, в 1708 году - центром Московской губернии. Население Москвы в то время составляло около 200 тыс. человек [1, с. 26]. Ещё в начале века в петровские времена застройку пытались регламентировать: в 1704 году был выпущен специальный Указ, устанавливающий правила застройки центра города. Согласно Указу здания в центре должны были располагаться «по линии, а не посередь дворов», что позволяло формировать линию застройки улиц.

После придания Санкт-Петербургу столичного статуса, что произошло в 1712 году, строительство в северной столице всячески стимулировалось. В 1714 году во всех городах России, в том числе в Москве, было запрещено каменное строительство. В том же году создаётся специальная государственная комиссия по сбалансированному развитию

*) Продолжение. Начало статьи «0б истории городского благоустройства и инженерных сетей Москвы. Часть I. История благоустройства древней Москвы. XIV-XVII века» опубликована в № 3 журнала «Academia. Архитектура и стролительство» за 2021 год. двух столиц - так называемая «Комиссия по устройству городов Москвы и Санкт-Петербурга». Москва продолжала сохранять своё значение «Первопрестольной»- важнейшего политического, религиозного, торгового и культурного центра России. Здесь находились представительства Сената и Синода, проходили коронации государей, отмечались важнейшие события религиозной и общественной жизни. Тем не менее в XVIII веке прирост населения Москвы был незначительным, вначале даже наблюдался его отток, и за сто лет численность населения увеличилось всего на 50 тыс. человек.

В работе Кузнецова 2020 года [3], посвящённой истории управления градостроительным процессом Москвы, дан анализ основных этапов развития столицы и показано, что городу были свойственны как периоды бурного роста, так и периоды стагнации и спада (см. часть 1 данной статьи, рис. 1).

В 1730 году в Москве начинают освещаться улицы. Первыми, согласно указу Анны Иоановны, освещение получили улицы Кремля, Белого города, Земляного города и Немецкой слободы, и это были металлические фонари на столбах, использующие фитили и конопляное масло.

Со второй половины XVIII столетия в Москве активно строятся городские дворянские усадьбы (Дом Пашкова, усадьбы Демидова, Барышникова и другие), а также крупные общественные здания (Воспитательный дом, Екатерининский дворец, городские больницы), которые имели благоустроенные и озеленённые прилегающие территории, источники водоснабжения (колодцы или скважины), внешнее освещение. Строились культовые здания и сооружения. 
Во второй половине XVIII века царские дворцы и усадьбы знати размещались в центре, за границами Земляного вала и в ближних пригородах. Крупное строительство постепенно формировало масштабные архитектурные ансамбли, выполненные преимущественно в стиле русского классицизма, в состав которых традиционно входили благоустроенные и озеленённые пространства, сады и парки.

В современном понимании городское благоустройство как особый вид градостроительной деятельности в Москве сложилось именно в XVIII веке. При этом значимость городского (общественного) благоустройства впервые была подтверждена указами Елизаветы Петровны в 1742 году, а затем Екатерины Второй в 1770-ом [1-3]. Однако вначале городское благоустройство развивалось медленно даже в центре - в границах Белого города.

К началу столетия Москва сохраняла слободской тип расселения и по сравнению с другими столицами Европы имела большую по площади территорию. Приведём некоторые данные по землепользованию на 1701 год [4, с. 70-83]. В границах Китай города - 62 га и 271 двор, Белого города - 451 га и 2532 двора, границах Земляного города - 1345 га и 7394 двора, а за границами Земляного вала было освоено 7410 га и 6117 дворов. Всего заселённые земли занимали 51\% городской территории, пашни - 10\%, сенокосы - 28\%, леса - 1\%. «Неудобья» составляли 10\% площади города. Москва в основном имела неплотную, преимущественно усадебную деревянную застройку, где проводилось традиционное благоустройство. В центре в границах Китай-города и Белого города дополнительные сложности для благоустройства создавали значительно обветшавшие к тому времени фортификационные сооружения.

На большей части территории Москвы на протяжении всего XVIII столетия решались такие приоритетные проблемы, как строительство и реконструкция домов после пожаров, организация источников водоснабжения, водоотведение и осушение, засыпка русел речек и ручьев или их очистка, устройство дренажа, строительство дорог, улучшение санитарного состояния территории. Иногда работы выполнялись собственниками земельных участков, многие общественные работы требовали средств из государственной казны.

Поддержание традиционного благоустройства на большей части территории Москвы являлось объективным условием жизни и землепользования того времени, что иногда задерживало процесс городских работ. В центральной части для её развития были необходимы планировочные преобразования и благоустройство, соответствующее новым градостроительным условиям. Анализ опыта рассматриваемого столетия показывает, что в градостроительстве и благоустройстве многое не только взаимообусловлено, но и зависит от реальных потребностей общества и не начинается раньше, чем это будет действительно необходимо. На рисунке 1 приводится фрагмент панорамы Москвы начала XVIII века.
Например, Указ 1585 года о придании улицам стандартных габаритов: 24 м по ширине - для главных, для второстепенных 12 м, - не спешил реализовываться и в XVIII веке. Даже Тверская, считавшаяся главной улицей города, где ещё в XVII столетии было устроено деревянное мощение тротуаров и проезжей части, на участке от современной Манежной до современной Пушкинской площади не имела установленной ширины.

Археологические изыскания подтверждают, что при благоустройстве улиц на протяжении всего XVIII столетия продолжают использовать деревянные мостовые и каменную «вымостку» из необработанного камня со связующим из глины. В то время, когда городские перевозки осуществлялись верхом и гужевым транспортом - в конных повозках, каретах, экипажах, в простых телегах - ноги и копыта лошадей были уязвимы, каменное мощение иногда прикрывали слоем сена или соломы.

Градостроительные преобразования готовились долго. Ещё в 1731-1739 годы (после отмены запрета на строительство каменных зданий) архитекторами И. Мичуриным и И. Мордвиновым создаётся широко известный «Мичуринский план» - первый точный картографический план города, необходимый для планирования его развития и строительства (рис. 2).

Важным практическим мероприятием по реконструкции и развитию Москвы в XVIII веке стало устройство в 1742 году Камер-Коллежского вала, длина которого была беспрецедентной - 37 километров. Вокруг вала проходил ров, было размещено 18 застав, находившихся около главных въездов в город.

Считается, что в отличие от древних укреплений Китайгорода, Белого Города и Земляного вала устройство КамерКоллежского вала не имело оборонительного значения, но оно было важно, поскольку зафиксировало на местности официальные границы города, ограничив его рост, организовав въезды в него и обеспечив надёжную охрану. На заставах проверяли документы и взимали пошлину.

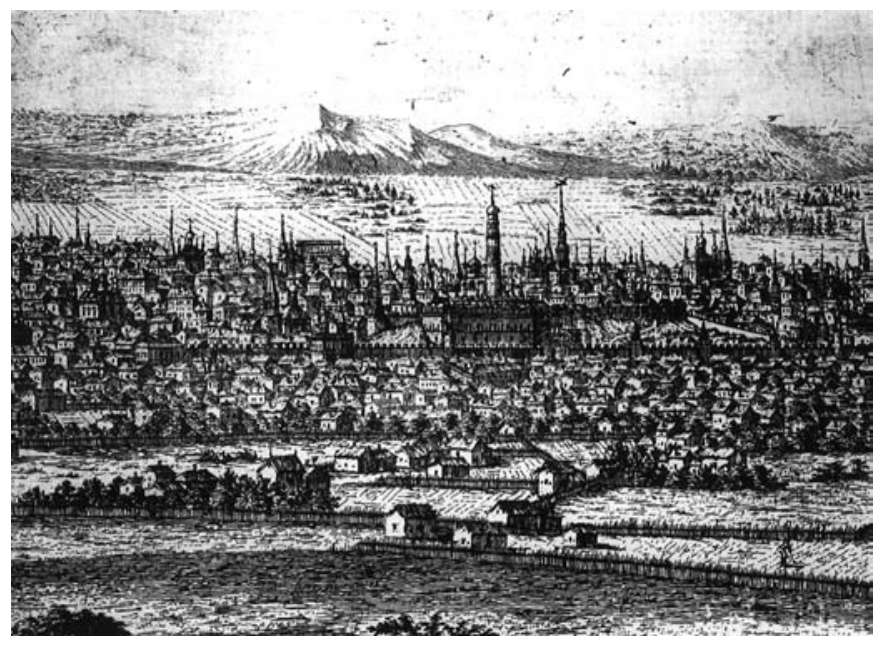

Рис. 1. Иоганн Ван Бликлант. Москва. Панорама. 1708 год. Фрагмент (источник: [2, с. 212]) 
В состав земель, ограниченных Камер-Коллежским валом, вошли исторические местности, расположенные за Земляным валом, - Пресня, Сущёво, Преображенское, Семёновское, Лефортово, Симоново, Даниловка, Девичье поле, Дорогомилово. Формирование Камер-Коллежского вала можно рассматривать как крупнейшее инженерное мероприятие, имеющее принципиальное значение для функционирования и благоустройства города. Созданный в Москве искусственный

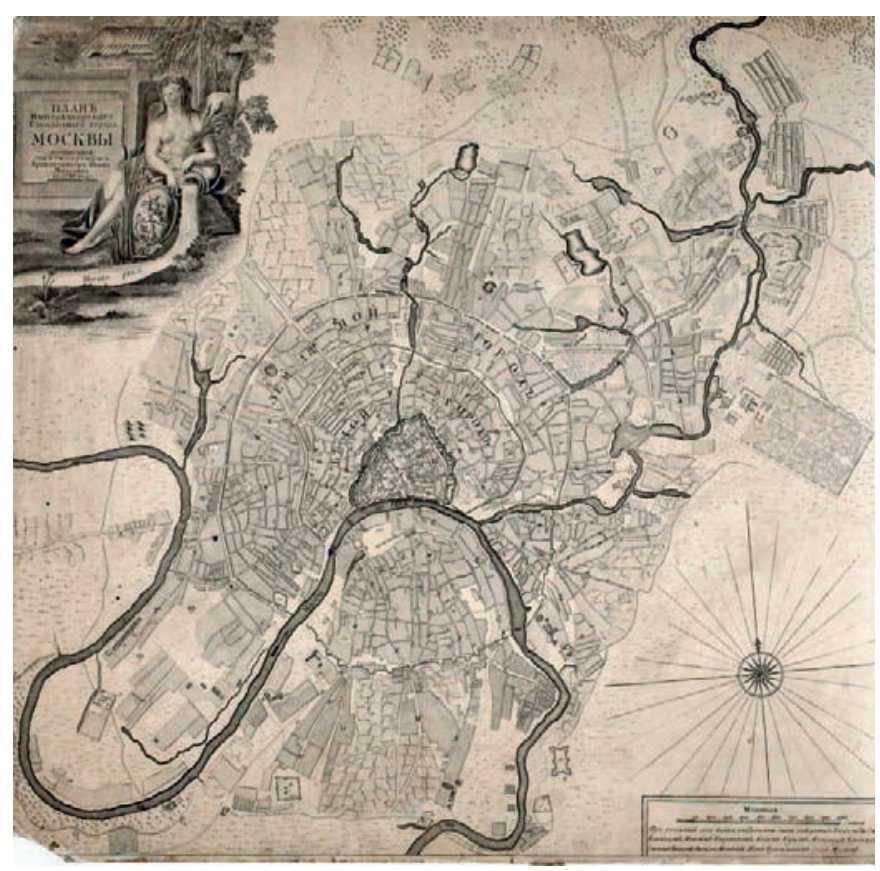

Рис. 2. Мичуринский план Москвы: «Вариант плана Императорскаго Столичнаго города МоСКВЫ сочиненной под смотрением Архитектора Ивана Мичурина в 1739 году. Карта гравирована на меди в формате $585 \times 494$ и раскрашена» (источник: http://retromap.ru/show_pid.php?pid=g2187)

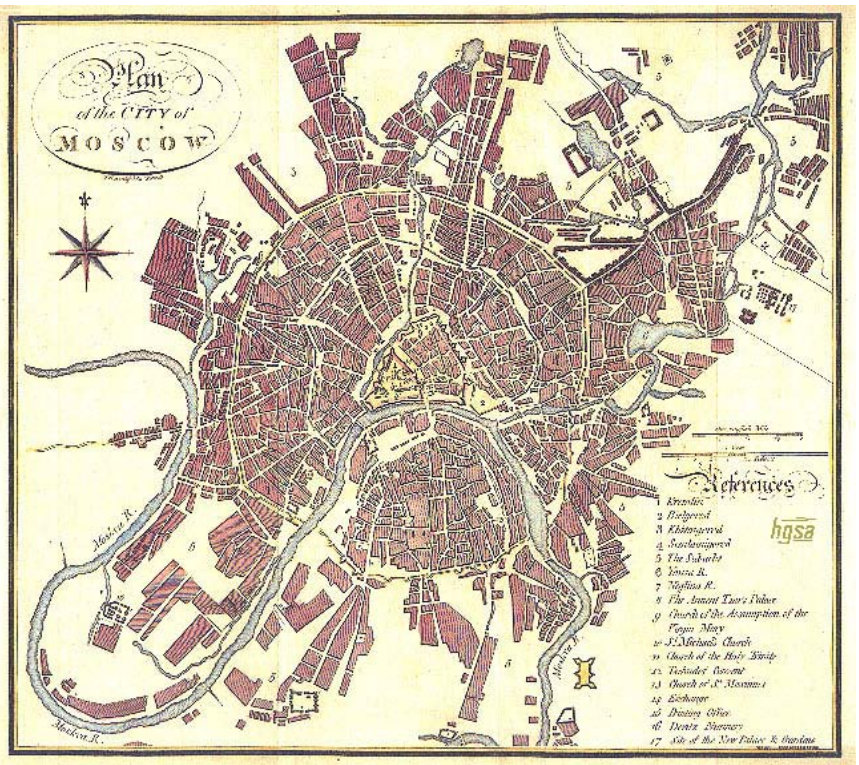

Pис. 3. План 1795 года (источник: http://retromap. ru/0917951) планировочный рубеж надолго обеспечил предпосылки для упорядочения строительства, его регламентации и проведения общественного благоустройства.

Если говорить о ходе планировочных преобразований, то сравнивая «Мичуринский» план 1739 года (см. рис. 2), «План царствующего града» 1763 года и последующие планы, в том числе - план конца XVIII века (рис. 3), можно сказать, что они существенно продвинулись. Приведённые планы Москвы существенно отличаются масштабом и детализацией пространственных данных, всё же можно увидеть и планировочные преобразования, а также изменения, происходившие в благоустройстве города за пятьдесят лет.

В 1774-1775 годы на основе детальных землеустроительных и межевых работ был разработан «Генеральный план Москвы». Для контроля за его реализацией и жёсткого регулирования планировки и застройки города был создан подчинённый генералу-губернатору Москвы «Каменный приказ». Его работу возглавил архитектор П. Кожин, составивший детальный проект перепланировки города и определивший перспективы его развития на конец XVIII - начало XIX века [1, c. 344].

Согласно Генплану, разработанному П. Кожиным, в границах Китай-города и Белого города можно было строить исключительно каменные дома, в границах Земляного вала - деревянные на каменном фундаменте. Это были важные противопожарные требования. На плане регламентированы местоположение мостов, направления и габариты уличнодорожной сети, определены меры по инженерному оборудованию территорий: места водозаборов, водосбросов и кладбищ.

Известно, что в екатерининские времена, во время эпидемии чумы, в целях обеспечения безопасности жителей Москвы были срочно предприняты меры по упорядочению городских кладбищ [1, с. 359-361]. До этого кладбища устраивали на территории храмов и монастырей. В 1770-1771 годы срочно организуются дополнительные общегородские кладбища. Первое - Лазаревское в Марьиной Роще с храмом архитектора В. Баженова, было реконструировано и расширено. Затем создано ещё шесть православных кладбищ - Дорогомиловское, Ваганьковское, Даниловское, Калитниковское, Миусское, Пятницкое, Семёновское, и два старообрядческих кладбища - Рогожское и Преображенское. Позже, в конце XVIII века был организован ряд «национальных» кладбищ для иноверцев.

В 1770-1780 годы «за излишней ветхостью и неудобностью» разбирают стены и сооружения Белого города, а в 1775 году был разработан проект устройства на их месте Бульварного кольца, включающего три полосы движения. Посередине - прогулочную озеленённую аллею, и с двух сторон - проезжие части бульвара. У пересечения Бульварного кольца с городскими улицами были запланированы и устроены большие площади - Тверская, Арбатская и другие. К концу XVIII века было выполнено их благоустройство. 
Стены Китай-города разобрали только в 1934 году при реконструкции центра, сохранив отдельные участки древнего сооружения. В конце столетия разбирают укрепления Земляного города, организуют площади на пересечении с крупными улицами и планируют устройство так называемого Садового кольца, впоследствии проект был реализован на нескольких участках, но благоустройство этих бульваров было утрачено в XX веке при строительстве крупной городской магистрали - Садовое кольцо.

В 1782 году «Каменный приказ» был ликвидирован, а его функции переданы так называемой «Управе Благочиния», однако приведённые примеры подтверждают доказанную историей пользу и необходимость жёсткого градостроительного регулирования развития городов и разработки генеральных планов для планирования общегородских работ по благоустройству, озеленению и инженерному обеспечению.

Известно, что в середине XVIII века в Москве был открыт первый университет, начали создаваться научные школы по естественно-научным дисциплинам. Для проведения исследований и решения практических задач часто приглашали известных учёных и специалистов из Европейских стран. Они участвовали в обосновании строительства зданий и сооружений, мостов, гидротехнических и защитных сооружений для борьбы с паводками и подтоплением, а также при организации водоснабжения города.

Недавно отмечалось 250-летие Московского городского водопровода. До середины XVIII века воду для питьевых и хозяйственных нужд брали из открытых водоисточников рек, ручьёв, озёр, прудов, которых было множество, и места водозаборов часто благоустраивали. Во второй половине столетия поверхностные водоисточники были сильно загрязнены нечистотами выгребных колодцев и ям, расположенных в границах домовладений.

После «чумного бунта» в 1779 году Екатерина II издаёт Указ «0 проведении чистых вод в Москву». Воду предлагалось подвести из Громового ключа в долине Яузы вблизи Мытищ. В 1781-ом начинается сооружение первого городского «Мытищинского» водопровода, подававшего воду в Москву. К сожалению, история водопровода не была гладкой, на пути транспортировки воды существовали огромные потери (утечки) воды. Ситуация улучшилась после реконструкции водовода и строительства в 1783-1784 годы Ростокинского акведука (рис. 4).

В конце XVIII века вода по водоводам самотёком подавалась в центр города к Сретенским воротам в Сухареву башню, во втором ярусе которой располагался чугунный резервуар, ёмкостью 7000 вёдер. К башне подъезжали многочисленные водовозы с бочками и развозили воду потребителям.

Следует высоко оценить прикладные научные достижения XVIII века - результаты специальных инженерных изысканий, проводившихся для целей развития градостроительства и благоустройства Москвы. Это не только масштабные межевые и землеустроительные работы, которые коснулись буквально каждого землепользования, это также изучение рельефа методами нивелирной съёмки, гидрохимические исследования водоисточников, исследования строительных свойств грунтов, гидрогеологические изыскания, инженерная гидрология как основа проектирования будущих масштабных гидротехнических сооружений.

В течение XVIII столетия в Москве построены каменные мосты, в целях защиты от паводков укреплены и оборудованы некоторые набережные. В конце века было реализовано два проекта укрепления и благоустройства Кремлёвской набережной - сначала В. Баженовым, впоследствии М. Казаковым, когда вдоль набережной прошла дорога и высажены деревья.

В 1783-1786 годы вдоль излучины Москвы-реки на противоположной стороне от Кремля на месте бывшего «болотастароречья» был проложен так называемый «водоотводной канал» с началом выше Большого Каменного моста и сливами в районе современной Шлюзовой набережной. Согласно [1, с. 172] строительство канала было связано с необходимостью ремонта Большого Каменного моста, который пострадал во время половодья 1783 года. Для ремонта потребовалось отведение воды каналом, длина которого составила 4 км, ширина 30-50 м, глубина первоначально была небольшая - 2 м.

Впоследствии в конце следующего столетия глубина канала увеличена. Некоторое время канал был судоходным, через канал перекинуты мосты, в том числе пешеходные, его берега постепенно были укреплены и благоустроены. При этом нужно учитывать не только инженерно-техническую и водохозяйственную роль строительства водоотводного канала, но и его градостроительное значение, изменившее планировку и застройку правобережной части исторической местности - Замоскворечья.

В екатерининские времена в Москве и её окружении ведётся значительное дворцовое и усадебное строительство, активно развивается садово-парковое искусство. Это объяснимо, поскольку климат Первопрестольной столицы больше располагает к загородному отдыху, чем климат Санкт-Петербурга.

Опыт садово-паркового искусства Москвы описан в трудах Горохова [5], Щукиной [6], Нащокиной [7] и других. Он показывает, что при устройстве дворцово-парковых и

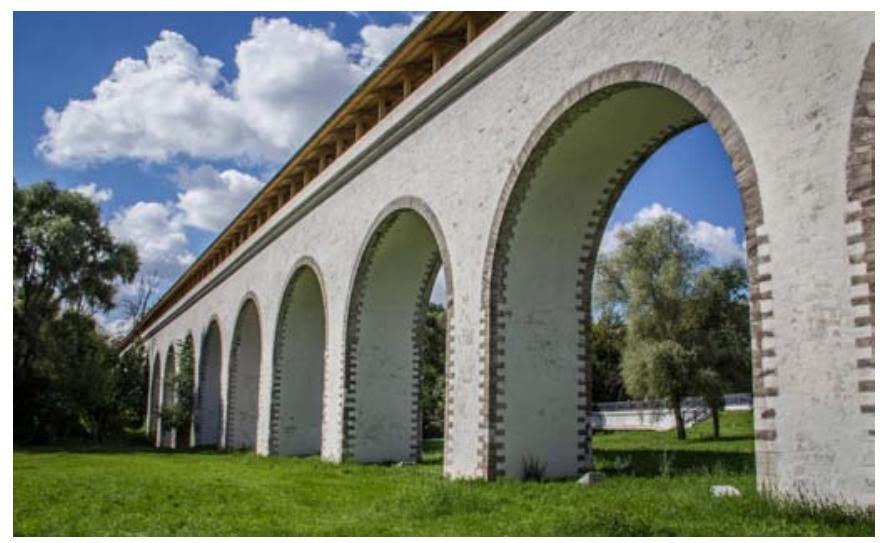

Pис. 4. Ростокинский акведук. Современное фото (фото из открытого доступа сети Интернет) 
усадебных ансамблей не копировались известные дворцовопарковые ансамбли мира, а в рамках господствующих стилей создавались образцы русского ландшафтного искусства, учитывающие особенности климата, ландшафта, почв, грунтов, национальные традиции.

Основоположником отечественного ландшафтного искусства стал агроном и ландшафтный архитектор В. Болотов. Подробные описания принципов, приёмов и технологий ландшафтного искусства конца XVIII -начала XIX века имеются в его научно-практических трудах [8; 9], которые в ту пору широко публиковались в популярном журнале «Экономический вестник» и массово использовались при создании садов и частных усадебных парков.

Методы и приёмы благоустройства и озеленения из частных садов и парков постепенно начинают использоваться в городском благоустройстве. Например, при благоустройстве Бульварного кольца, как известно, применялся породный состав насаждений, получивший распространение в московских и пригородных усадебных парках, адаптированный к местным условиям - преимущественно липа мелколистная, а также дуб, вяз, ясень.

XIX - начало XX века. Масштабные преобразования после пожаров Москвы. Рост населения, промышленности, формирование железнодорожного узла и городского общественного транспорта. Развитие улично-дорожной сети, дифференциация производственных, жилых и общественных функций города как основы благоустройства и инженерного обеспечения

В начале XIX века прирост населения и развитие территорий Москвы были незначительными. Градостроительная ситуация после пожара Москвы 1812 года и последующей победы над Наполеоном меняется в процессе восстановления города. В результате происходят существенные изменения в пространственной организации и использовании территорий, в благоустройстве города. Реконструкция Москвы началась практически сразу после ухода войск Наполеона.

Мы уже говорили, что ещё на рубеже XVIII-XIX веков создана Комиссия по устройству городов Москвы и СанктПетербурга [1, с. 376-377]. После пожара Москвы в 1812 году деятельность комиссии стала ещё более активной, в 1813 году была создана специальная Комиссия для строения Москвы под руководством князя Цицианова. В комиссию вошли как чиновники, так и архитекторы - Бовэ, Стасов, Жилярди и другие. Комиссия включала «Чертёжную» с двумя отделениями - «Землемерным» и «Архитектурным» [1, с. 376-377]. План Москвы, составленный комиссией, впервые включал ряд целевых мероприятий по городскому благоустройству, в том числе по устройству площадей и набережных, которые для борьбы с наводнениями укрепляли «диким камнем» (Раушская набережная, 1830). Большой вклад в московское благоустройство в то время внёс знаменитый фельдмаршал и сенатор Прозоровский [1, с. 337, 664].
В основу восстановления были положены задачи перспективного развития - крупные планировочные мероприятия по реорганизации планировочной структуры города, развитию улично-дорожной сети, инженерных сетей, по созданию благоустроенных общественных пространств и озеленённых территорий, которых ранее в планировке Москвы не было. Несмотря на огромные утраты и экономические трудности восстановление Москвы шло достаточно быстро и было практически закончено в двадцатых годах.

Нужно сказать, что существенная часть перепланировок, проведённых в период восстановления, были предусмотрены Генпланом П. Кожина, но раньше не были реализованы. Началом восстановления Москвы стали мероприятия по реализации прежних решений о разборке некоторых укреплений Китай-города, по завершению разборки оставшихся сооружений Белого города и Земляного вала. Часть Бульварного кольца значительно пострадала при пожаре и требовала восстановления.

В некоторых стенах Китай-города позже были устроены проломные ворота, что позволило связать территории исторического центра, расположенные по разные стороны стены. Некоторые укрепления Китай города были разобраны только в 30-х годах XX века, а часть сохранились до настоящего времени и реставрируются как ценнейшие объекты культурного наследия (см. часть I). Восстановление города шло достаточно быстро.

В городском хозяйстве ещё в начале XIX века были определённые успехи. Считается, что сооружение Мытищинского водопровода завершено в 1805 году, впоследствии построены водоводы, а на площадях - водоразборные фонтаны. Первый фонтан устроен на Трубной, затем на Сухаревской, в Александровском саду. В начале XIX века были запущены еще два водопровода, забиравшие воду из реки Москвы. Первый рассчитан на 34 тыс. вёдер воды, второй - на 100 тыс. Водопроводы обслужили районы Тверской, Зацепы, Серпуховской, Калужской, Полянки и Пятницкой.

В 1825 году в Москве появились первые простейшие водосточные каналы - Самотёчный и Неглинный. Однако до конца XIX века нечистоты из выгребных колодцев и ям вывозились ассенизаторами-золотарями, но создание настоящей городской канализации было отложено до конца века.

К 1800 году [1, с. 600] в Москве было установлено 6559 фонарей. При пожаре 1812 года фонари сгорели, и к 1814 году было восстановлено 1262, а к 1850-ому - 8000 фонарей, которые обслуживались пятьюстами фонарщиками.

Уже в начале XIX века орография исторической местности Москвы значительно трансформирована подсыпкой и срезкой грунта, засыпкой оврагов, малых рек, ручьёв и болот. Значительных земляных работ потребовало завершение разборки сооружений Белого города, Земляного вала и необходимая планировка территории. В связи с высоким риском подтопление проводится дренаж с последующим водоотведением. В качестве противопожарной меры в тече- 
ние всего столетия продолжается обводнение - устройство искусственных прудов.

В 1830 году в трубы были заключены реки Неглинная и Самотёка, позже у стен Кремля был спущен Красный пруд, на месте которого устроен Александровский сад.

Большое внимание в то время уделялось вопросам создания и благоустройства общественных пространств и озеленённых территорий общего пользования. Небольшие благоустроенные городские площади, сады и скверы создаются на месте сноса ветхих строений и в периферийных частях города. Уже в первой половине XIX века городские праздники на площадях, прогулки в городских садах и парках становятся традицией для различных слоёв населения. В 1840 году в городе появляется первый общественный транспорт - «линейки».

К 30-40 годам восстановленная Москва приобрела облик «дворянского города» [1, с. 36], но в ней уже появляются приметы будущего масштабного развития. После окончательной разборки Земляного вала получили дополнительное развитие территории с его внешней стороны, начинает формироваться Садовое кольцо, а скорее площади в местах пересечения с улицами - Самотёчная, Зубовская, Смоленская, Кудринская и другие. Территории площадей постепенно благоустраивались, благоустройство бульваров откладывалось.

В 1820 году у пересечения Тверской улицы с Земляным валом была сформирована и благоустроена большая площадь, которая сегодня называется Триумфальной, здесь в 1827 году в честь победы над Наполеоном была установлена каменная Триумфальная арка высотой 28 метров (архитектор 0. Бовэ), которая впоследствии была утрачена. В 1966 году воссоздана на Кутузовском проспекте. На рисунке 5 представлен план города к концу 30-х годов XIX века.

Население и территория Москвы начинают быстро расти во второй половине XIX века, особенно после отмены крепостного права в 1861 году, в результате быстрого роста капитализма и с началом строительства железных дорог.

За вторую половину XIX века население Москвы увеличивается втрое и к началу XX века составило около 1 млн человек, а к 1917 году - 1,8 млн человек [1, с. 26]. Именно железнодорожная инфраструктура стала главным фактором, стимулирующим градостроительное развитие, планировочные преобразования, активизирующим благоустройство, транспортное обслуживание и инженерное обеспечение в Москве. К 1913 году в Москве насчитывается более тысячи предприятий, работают биржа, множество банков и финансовых учреждений. В конце XIX - начале XX века бурно развиваются наука и культура, сферы образования, медицины, здравоохранения. Активно ведутся строительство и благоустройство. Строятся жилые дома, гуманитарные и технические высшие и средние учебные заведения, крупные клиники, больницы, библиотеки, торговые здания. Все размещаемые объекты имеют благоустройство и озеленение.

В городе обустраиваются специальные пространства для массовых мероприятий (у Новинской заставы и на Ходынском поле). В новых общественных условиях ярко проявляется направленность градостроительства и благоустройства на «общественное благо». На рисунке 6 приводится план города Москвы 1911 года - «Суворинский план», на котором наглядно

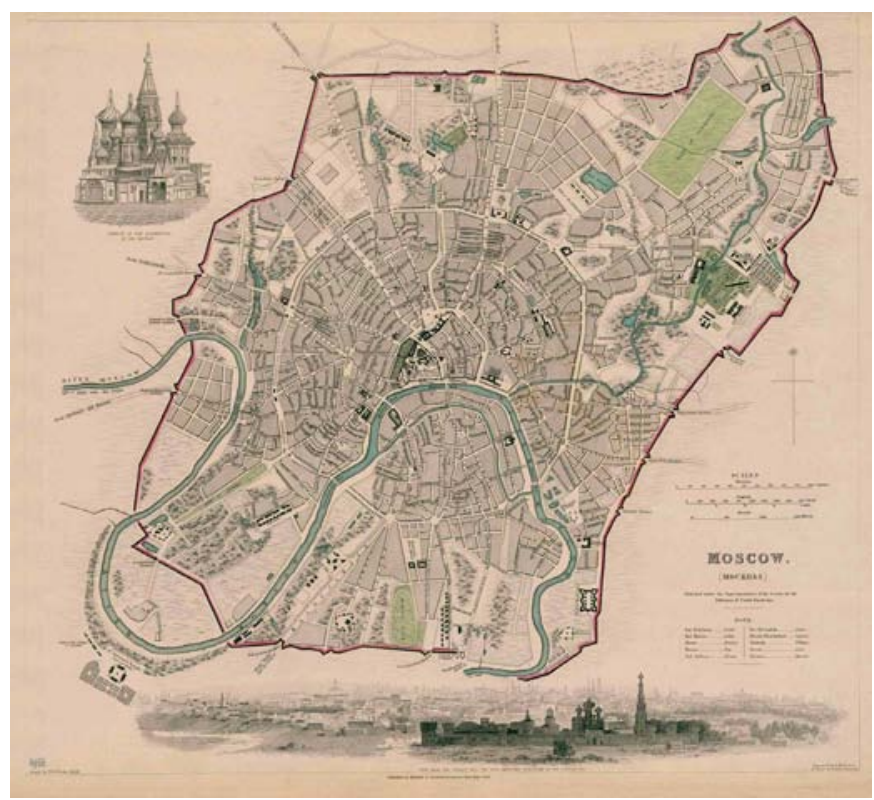

Pис. 5. План Москвы. 1836 год (источник: http://retromap. ru/081836)

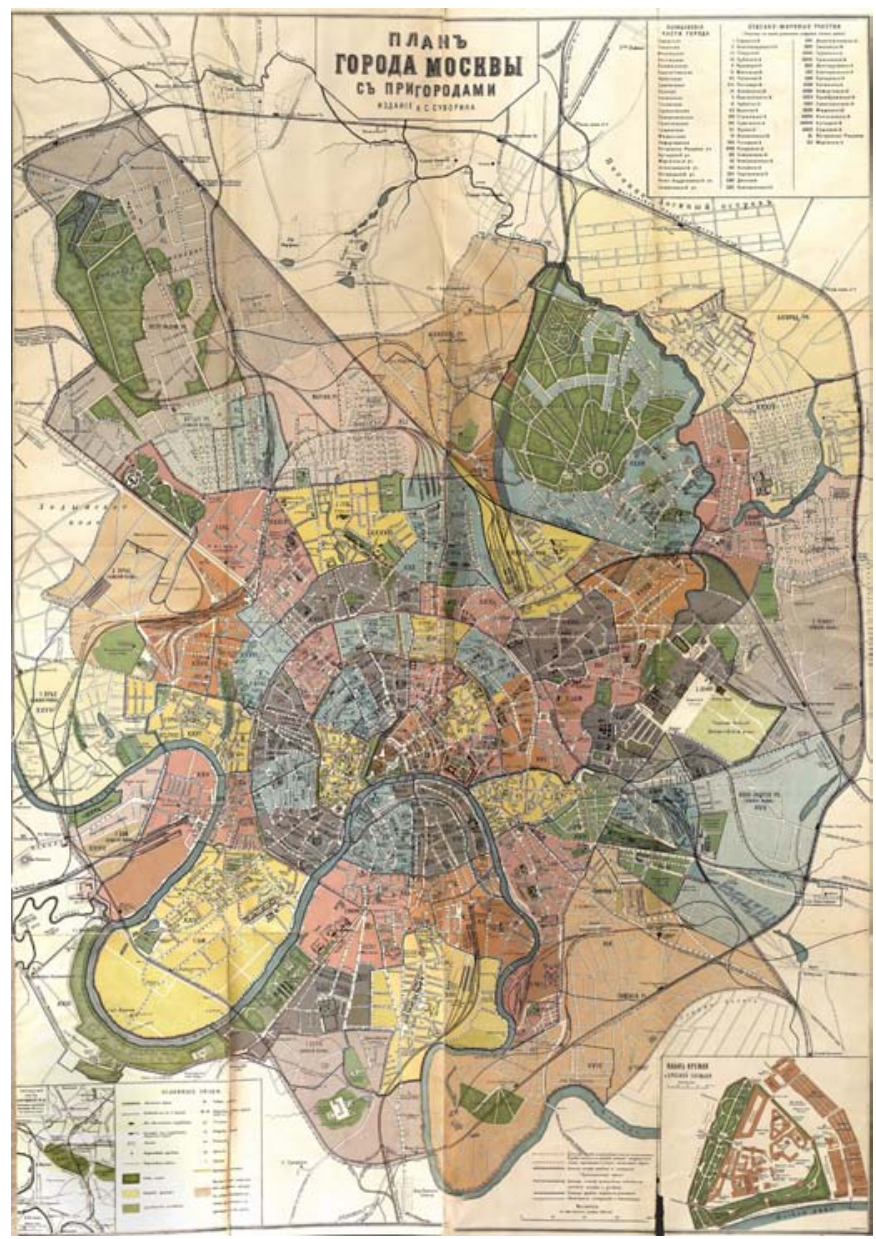

Рис. 6. План Москвы («Суворинский план»). 1911 год (источник: http://retromap.ru/0719114) 
видно градостроительное развитие города к началу XX века с относительно чётким функциональным зонированием и озеленёнными территориями общего пользования.

По данным [1, с. 37] Николаевская (Октябрьская) железная дорога была построена в 1851 году, Нижегородская и Северная в 1862, Рязанская - в 1864, Курская дорога - в 1868, Белорусская - в 1870, Рязанско-Уральская - в 1862-1864, Киевская - в 1899, Савеловская - в 1900, Балтийская - в 1901. В 1903-1908 вокруг Москвы была построена Окружная железная дорога. В те годы железнодорожная инфраструктура глубоко вошла в ткань города, и это сказалось на благоустройстве городских территорий.

На железнодорожные вокзалы были ориентированы (переориентированы) все внутригородские транспортные связи и маршруты городского транспорта [1, с. 177]. В 1872 в Москве построены городские железные дороги с конной тягой (конка) [1, с. 382]. Депо конки размещалось на Миусcax, недалеко от Тверской заставы. Позже, в 1911 по рельсам конки пустили трамвай на электрической тяге [1, с. 818]. Для этого на Раушской набережной была построена специальная электростанция.

Для внутригородского пассажирского движения используется построенная в 1903-1908 годах Малая московская кольцевая железная дорога с пятнадцатью станциями и благоустроенными пристанционными площадями. Некоторые станции приближены к производственным территориям, другие - к местам проживания, третьи - к зонам отдыха (Коптево,
Петровско-Разумовская, Серебряный бор и другие). На рубеже веков ведётся массовое строительство загородных дач. Для связи с дачными пригородами и с городами Московской губернии приспосабливают железные дороги Московского железнодорожного узла, которые становятся не только внешними, но также пригородно-городскими.

Во второй половине XIX века происходит ускоренное развитие инженерных сетей. Когда качество водопроводной воды стало неудовлетворительным из-за загрязнения источников, начинают строиться местные (копаные или буровые) водозаборы и местные водопроводы - Ходынский, Андреевский, Калужский Преображенский. В 1888 году вблизи Яузских ворот была пробурена первая глубокая артезианская скважина глубиной 455 м, предназначенная для водоснабжения Семёновского и Таганки. После строительства в 1892 году у Крестовской заставы двух шестиэтажных водонапорных башен высотой 40 м и диаметром 20 м с ёмкостью резервуаров по 1850 куб. м каждая, строительства Алексеевской насосной станции, реконструкции подводящих сетей работа Мытищинского водопровода становится эффективнее. Однако только после многочисленных ремонтов к 1902 году производительность этой системы достигла 3350 вёдер воды в сутки, а постоянные исследования говорили о быстром истощении источника и его загрязнении.

Считается, что падение производительности подземных водоисточников Москвы, в том числе Мытищинского, было

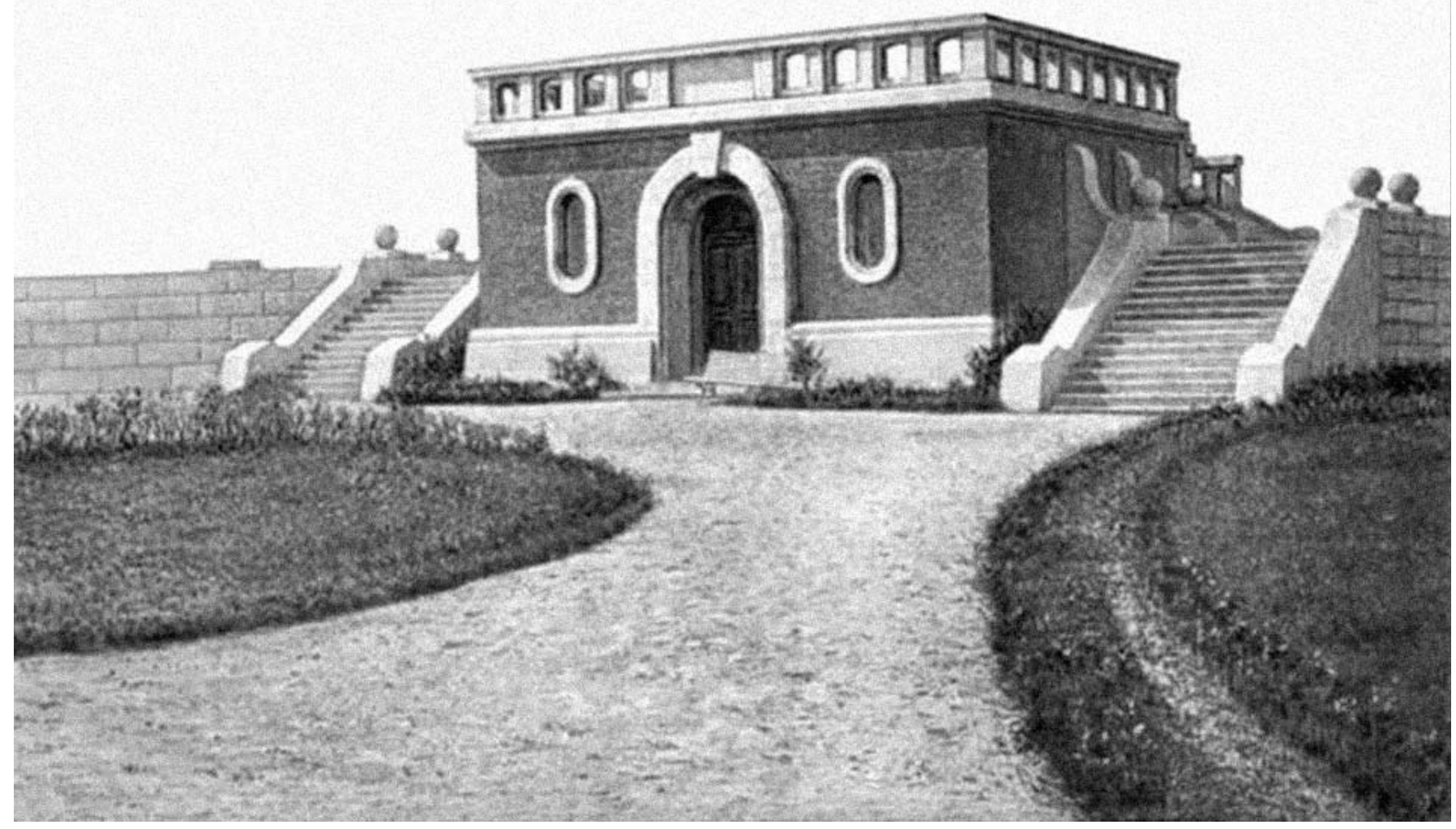

Рис. 7. Рублевская насосная станция. Фото начала XX века (источник: $[1$, с. 173]) 
связано с формированием воронки депрессии. Критическая ситуация с водоснабжением Москвы преодолена за счёт строительства и ввода в 1902 году Рублёвкой водопроводной станции с водозабором из реки Москвы. Качество воды на водозаборе контролировалось лабораторными исследованиями. Согласно [1, с. 173], к 1917 году протяжённость сети городского водопровода составила 500 км, суточная подача воды 170 тыс. куб. м. Уже в эти годы рассматривался вопрос и обоснования проектов переброски стока рек Волги и Оки для водоснабжения Москвы. На рисунке 7 приводится фото Рублёвской насосной станции в начале XX века.

Согласно [1, с. 346], первый проект городской канализации со смешанными сточными водами был предложен инженером Поповым в 1874 году. Его отклонили, и к 1892 году разработан проект с раздельной канализацией хозяйственно-бытовых и дождевых вод. В 1893 году начинает строиться централизованная городская канализация. Дождевые и условно-чистые воды могли сбрасываться на рельеф и в водоёмы без очистки. Построенная к 1898 году система городской канализации, предназначенная для очистки хозяйственно-бытовых и приравненных к ним сточных вод, включала в себя канализационные сети, насосные станции и очистные сооружения на полях орошения. Сначала, к 1898 году, были построены Люблинские поля орошения,

В 1907-1912 годы разрабатывается проект второй очереди, который предусматривает канализование территории в границах Камер-Коллежского вала с очисткой на Люберецких полях орошения. Уникальные исследования и инженерные решения при строительстве московской канализации в 1911 году на международной выставке в Брюсселе были отмечены Золотой медалью «За санитарное оснащение и содержание городских территорий». К 1917 году к канализации было подключено 50\% домовладений центральной части города и $28 \%$ по городу в целом, при этом водосброс на поля орошения составил 100 тыс. кв. м в сутки.

В 1866 году масляные фонари начинают переводить на керосин, одновременно или даже чуть раньше - в 1863 году,

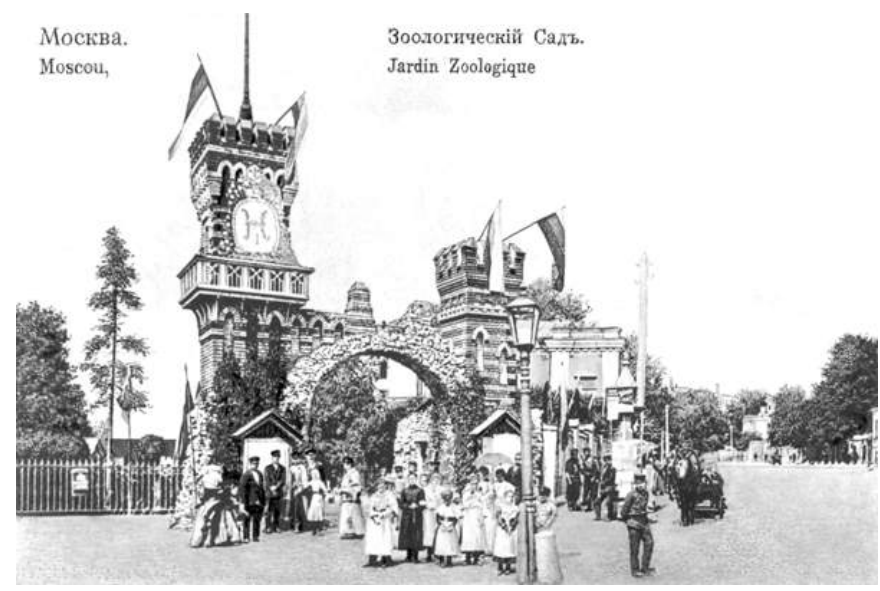

Рис. 8. Московский зоопарк. Фото начала ХХ века (источник: [1, c. 313]) появляется газовое освещение с прокладкой газовых труб. К 1868 году построен специальный газовый завод, в 1914ом - специальный газовый завод для выпуска газа высокого давления. Заводы принадлежали городу.

На рубеже XIX-XX веков в освещении начинает использоваться электричество. Согласно [1, с. 600], в 1883 году появились первые электрические дуговые фонари компании «Сименс», которая была признанным мировым лидером в этой области. В 1900 году электроосвещение устроено в Кремле, у храма Христа Спасителя, затем стало быстро распространяться по городу. В 1906-ом открывается фабрика по производству электродуговых ламп, но окончательно электроосвещение вытеснило другие виды уличного освещения только в начале 20-х годов XX века. Электричество использовалось в освещении и в городском транспорте - при организации трамвайного движения. В 1872 году в Москве появились линии телеграфа, в 1898-ом Москву и Петербург связала линия междугородного телефона. Отопление и горячее водоснабжение были индивидуальными.

Многие подходы и технические решения благоустройства начала XX века обобщаются в 1912 году выдающимся гражданским инженером В.Н. Семёновым в книге «Благоустройство городов» [10]. Эта работа, имевшая фундаментальное значение для инженеров-градостроителей своего времени, сегодня даёт нам возможность познакомиться с общими подходами и инженерно-техническими решениями по благоустройству тех лет. В книге много внимания уделялось именно инженерным вопросам городского благоустройства, строительству городских улиц и дорог, озеленению.

В середине XIX века устраивают сад «Эрмитаж» на Петровке, сад «Аквариум» на Триумфальной, два сквера в Охотном ряду.

Впоследствии, на рубеже XIX-XX веков Москва благоустраивает бульвары - Гоголевский, Тверской, Чистопрудный, Рождественский, Яузский. Бульваров стало двадцать. Некоторые не сохранились. При расширении Тверской утрачен самый протяжённый и широкий Тверской бульвар, проходивший от Триумфальной площади до Белорусского вокзала и благо-

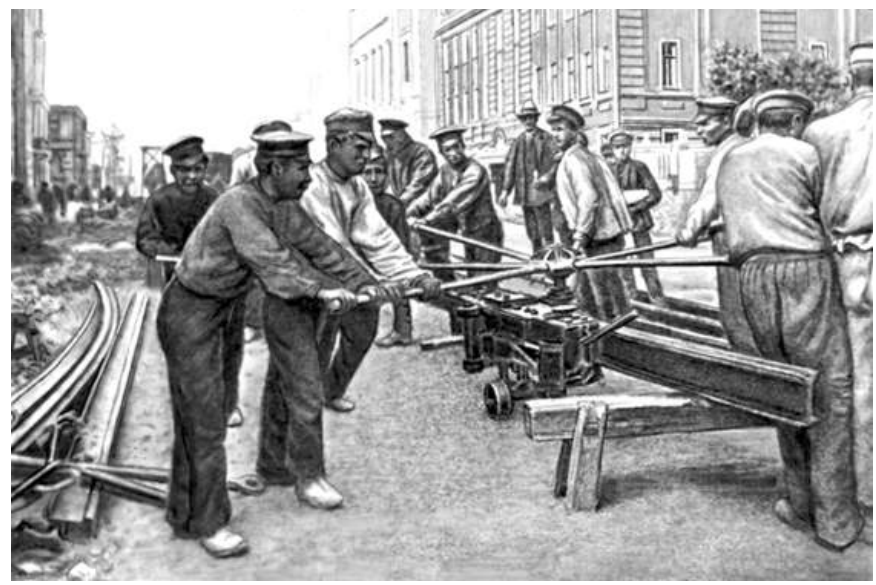

Pис. 9. Процесс укладки трамвайного полотна в начале XX века (источник: [1, с. 818]) 
устроенный в начале XX века. Позже было утрачено и его продолжение до Петровского парка.

К настоящему времени сохранились: Славянский (самый широкий), Новинский, Зубовский, Цветной, переходящий в Самотёчный, и другие исторические бульвары.

Во второй половине XIX века, когда создавались озеленённые территории общего пользования, их земли переходили в общественное (муниципальное) пользование. В это время так были оформлены земли, расположенные в окружении Петровского путевого дворца, когда здесь создавался общедоступный Петровский парк, который был очень популярен у москвичей.

0снованный в 60-х годах XIX века Московский зоопарк в 1905 году после пожара был реконструирован и стал крупнейшим в Европе. На рисунке 8 фото Московского зоопарка начала XX века.

С приходом муниципального управления существенно повышается внимание к городскому благоустройству, обустройству городских улиц и дорог и озеленению. Ранее мы говорили, что ещё в 1585 году в Москве был издан Указ о придании главным улицам ширины 24 м, а второстепенным - 12 м. Указ не работал практически до середины XIX века [11], поскольку именно с этого времени действительно повышаются требования к благоустройству площадей, городских улиц и дорог.
C середины XIX века в Москве появляются первые проспекты. Петровский проспект был организован при планировке старого Петровского парка, в границах которого появилось несколько широких улиц-аллей, названных проспектами.

Анализ показывает, что к концу XIX - началу XX века благоустройство Москвы приобретает вид характерный для крупного торгово-промышленного города с достаточно развитым общегородским общественным центром, реализующим разнообразные функции, с преимущественно жилыми кварталами в срединной части - за Садовым кольцом, и чередующимися транспортными, промышленными, жилыми зонами. Однако существенным отличием было достаточно большое количество озеленённых территорий в центре и в периферийных частях города.

Застройка города в то время выдвигала минимальные требования к благоустройству и озеленению внутриквартальных и придомовых территорий. В эти годы и особенно в начале $X X$ века благоустройство приурочено к значимым для города крупным градостроительным проектам, и проводилось оно не всегда за счёт городских средств - часто за счёт застройщиков и благотворителей.

Благоустройство в Москве к концу XIX - началу XX веков курируется Министерством внутренних дел и Управой города,

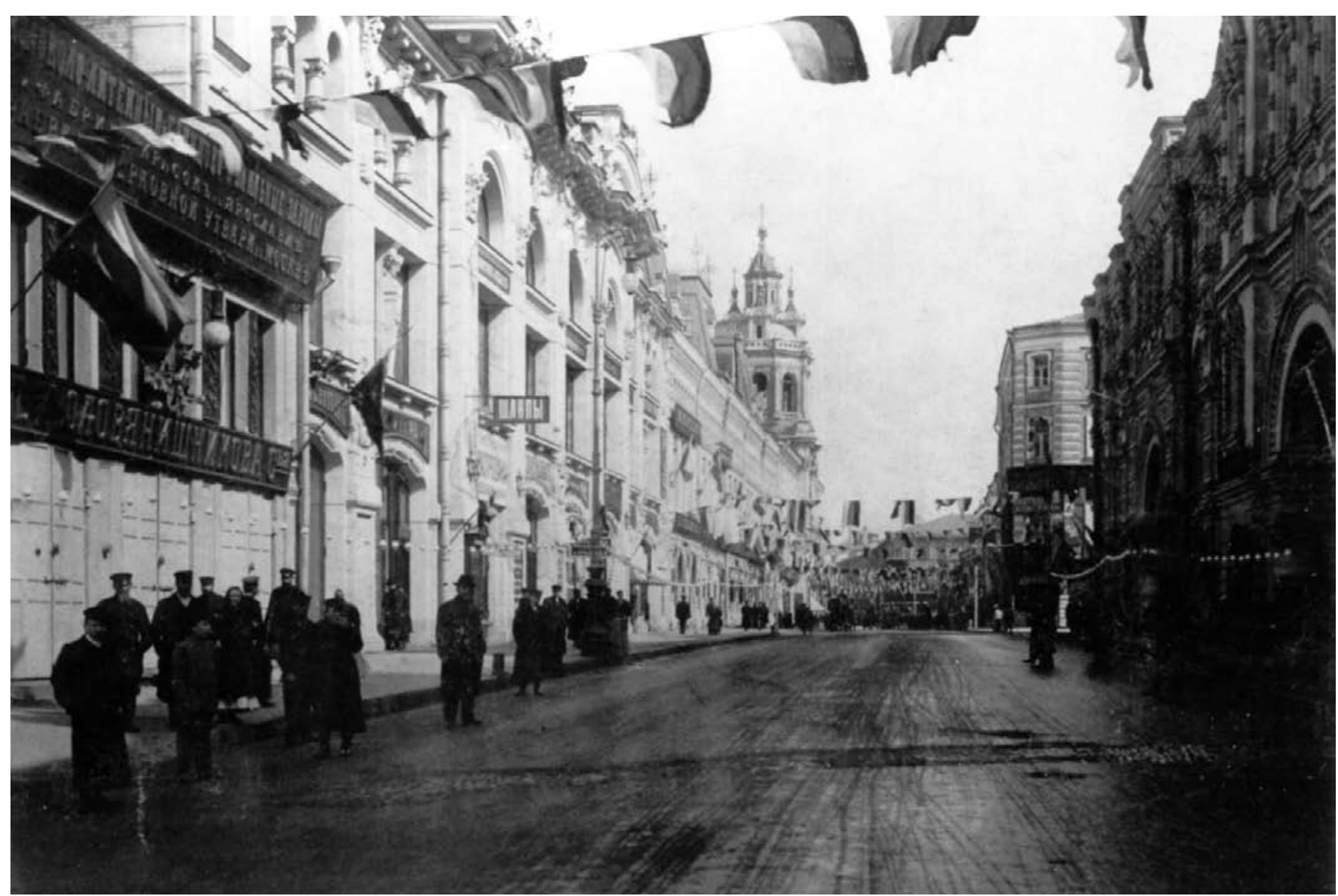

Рис. 10. Никольская улица. Испытание 1-го асфальта (фото из открытого доступа сети Интернет) 
при этом очень значима роль муниципального управления и Городской думы. В основном городское благоустройство заключалось в прокладке, реконструкции и ремонте городских улиц и дорог, в строительстве мостов.

B XIX - начале XX века при благоустройстве главных улиц и площадей часто применяется мощение из необработанного камня, а в качестве связующего используют глину. Устраивают приподнятые тротуары, применяют тёсаный бортовой камень. Как свидетельствуют многочисленные фотоматериалы рассматриваемого периода, мощение второстепенных улиц часто проводилось с использованием необработанного известняка и дроблёного кирпича, образующегося при разборке зданий, и иногда без устройства тротуаров.

В основном по трассам конки, а потом трамвая на бетонное основание укладывают обработанную брусчатку. В конце XIX века гранитную мостовую из «дорогой» обработанной брусчатки устраивают на Красной площади и на Васильевском спуске. Такие покрытия получили также бульвары Бульварного кольца, которые благоустраивались в начале XX века, в том числе Чистопрудный. На рисунке 9 показан пример устройства трамвайного полотна в начале XX века. Однако в некоторых периферийных районах для мощения дорог используют булыжные мостовые, для отведения дождевого стока устраивают открытые лотки и дренажные канавы.

Поскольку на рубеже XIX-XX веков ещё много ездили на лошадях - в экипажах и верхом, часть поверхности улиц и площадей иногда оставляли грунтовой, выполняя укрепление грунта. Тротуары для удобства пешеходов иногда мостили деревом. Как правило, при благоустройстве улиц устраивали водоотводные лотки, иногда с дождеприёмными решётками. Для отведения поверхностного стока с городских улиц и дорог к местам водосброса в этом случае укладывались керамические водосточные трубы.

В 1873 году при обустройстве улиц в Москве начинают применять асфальтовые покрытия. Первой улицей, получившей асфальтовое покрытие, стала Никольская, однако до конца рассматриваемого периода асфальтировка улиц большого распространения не получила.

В данном научном обзоре мы лишь кратко изложили и проиллюстрировали наиболее важные направления, достижения и проблемы благоустройства и развития инженерных сетей Москвы с XIV по начало XX века.

Анализ истории благоустройства и развития инженерных сетей Москвы показал, что инженерное благоустройство и создание инженерных сетей являются важнейшими направлениями градостроительной деятельности и не могут рассматриваться в отрыве от неё. Более того, решение инженерных задач и проблем на протяжении многих веков определяло градостроительное развитие и условия существования города, обеспечивая при этом жизненно важные требования безопасности, снабжения ресурсами, в том числе питьевой водой, санитарные требования и удобства для проживания населения постоянно растущего города.
По мере развития научно-технического прогресса изменялись требования к благоустройству и инженерному обеспечению, и в основном они соответствовали этапам градостроительного развития. Именно инженерное благоустройство и развитие сетей определяло пространственное развитие и социальную направленность градостроительства. Будем надеяться, что в этом направлении Москва будет развиваться и в дальнейшем.

\section{Лuтература}

1. Москва: Энциклопедия / Гл. ред. С.0. Шмидт; Сост.: М.И. Андреев, В.М. Карев. - М. : Большая Российская энциклопедия, 1997. - 976 с.

2. Швидковский, Д.О. Исторический путь Русской архитектуры и его связи с мировым зодчеством / Д.0. Швидковский. - М. : Архитектура-С, 2016. - 513 с.

3. Кузнецов, С.О. Анализ деятельности по управлению градостроительным процессом в Москве нач. XVIII - кон. XX века / С.0. Кузнецов // Academia: архитектура и строительство. - 2020. - № 1. - С. 29-39.

4. Гутников, В.А. Экологические и топономические потери природных объектов города Москвы/ В.А. Гутников, В.Н. Страхова // Градостроительство. - 2021. - № 1 (71). - С. 70-83.

5. Горохов, В.А. Зелёная природа города. Садово-парковое искусство России : В 2-х томах / В.А. Горохов. - М. : Архитектура-С.

6. Щукина, Е.П. Подмосковные усадебные сады и парки конца XVIII века / Е.П. Щукина. - М. : Институт наследия, 2007. - 383 c

7. Нащокина, М.В. Русские сады: XVIII - первая половина XIX. - М. : Арт-Родник,2007. - 255 с.

8. Болотов, А.Т. Замечания о превращении простых натуральных лесочков в увеселительные / А.Т. Болотов // Экономический магазин. - 1784. - Ч.20.

9. Болотов, А.Т. 0 направлении старых садов / А.Т. Болотов // Экономический магазин. - 1784. - Ч.12.

10. Семёнов, В.Н. Благоустройство городов / В.Н. Семёнов - М. : Типография. П.П. Рябушинского, 1912. - 225 с.

11. Саваренская, Т.Ф. История градостроительного искусства. Том 1 Рабовладельческий и феодальный периоды / Т.Ф. Саваренская. - М. : Архитектура-С, 2019. - 442 с.

12. Романюк, С.К. Москва за Садовым Кольцом / С.К. Романюк. - М. : АСТ, 2001. - 896 с.

13. Полякова, Г.А. Парки Москвы: экология и флорестическая характеристика / Г.А. Полякова, В.А. - М. : ГЕОС, 2000. - 406 c.

14. Беляева, Е.Л. Методология, методика, опыт работ по сохранению для современного использования парка усадьбы Михалково / Е.Л. Беляева, И.А. Маркина, Р.Г. Могинов // Academia. Архитектура и строительство. - 2020. - № 1. - С. 78-84; № 2. - С. 113-120.

15. Волкова, С.Д. Парк и человек. Очерки и статьи о роли парков в жизни общества / С.Д. Волкова, С.В. Сочивко. - СПб : 
Зелёная стрела, 2019. - 57 с. 16. Лихачева, Э.А., Экологические проблемы Москвы за 150 лет : Монография / Э.А. Лихачева, Е.Б Смирнова / под ред. Д.А. Тимофеева. - М. : Полиграфист, 1994. - 256 c.

17. Инженерное благоустройство городских территорий / В.Э. Бакутис, В.А. Горохов, Л.Б. Лунц, О.С. Расторгуев. - М. : Стройиздат, 1979. - 237 с.

18. Горохов, В.А. Инженерное благоустройство городских территорий и населенных мест / В.Э. Бакутис, В.А. Горохов, Л.Б. Лунц, 0.С. Расторгуев. -М. : Стройиздат, 1994. - 453 с.

19. Инженерная подготовка и благоустройство городских территорий / В.В. Владимиров, Г.Н. Давидянц, О.С. Расторгуев, В.Л. Шафран. - М. : Архитектура-С, 2004. - 200 с.

20. Федосюк, Ю.А. Москва в кольце Садовых / Ю.А. Федосюк. - М. : Московский рабочий, 1983. - 447 с.

21. Беляева, Е.Л. Особенности благоустройства и озеленения исторических городов. Подходы и Методические рекомендации : Монография / Е.Л. Беляева. - М. : Экон-Информ, 2021. - 270 c.

\section{References}

1. Shmidt S.0. (ed.)/ Moskva: Entsiklopediya [Moscow: Encyclopedia], Compiled by: M.I. Andreev, V.M. Karev. Moscow, Great Russian Encyclopedia, 1997, 976 sp. (In Russ.)

2. Shvidkovskii D.0. Istoricheskii put' Russkoi arkhitektury i ego svyazi s mirovym zodchestvom [Historical path of Russian architecture and its connection with world architecture]. Moscow, Arkhitektura-S Publ., 2016, 513 sp. (In Russ.)

3. Kuznetsov S.0. Analiz deyatel'nosti po upravleniyu gradostroitel'nym protsessom v Moskve nach. XVIII - kon. XX veka [Analysis of activities for the management of the urban planning process in Moscow early. XVIII -late XX century]. In: Academia: arkhitektura i stroitel'stvo [Academia: architecture and construction], 2020, no. 1, pp. 29-39. (In Russ., abstr. In Engl.)

4. Gutnikov V.A., Strakhova V.N. Ekologicheskie i toponomicheskie poteri prirodnykh ob"ektov goroda Moskvy [Ecological and toponomiclosses of natural objects of the city of Moscow]. In: Gradostroitel'stvo [Urban planning], 2021, no. 1 (71), pp. 70-83. (In Russ.)

5. Gorokhov, V.A. Zelenaya priroda goroda. Sadovo-parkovoe iskusstvo Rossii [Green nature of the city. Gardening art of Russia:]: In 2 Volumes. Moscow, Arkhitektura-S Publ.. (In Russ.)

6. Shchukina, E.P. Podmoskovnye usadebnye sady i parki kontsa XVIII veka [Manor gardens and parks near Moscow at the end of the 18th century]. Moscow, Institute of Heritage Publ., 2007, 383 p. (In Russ.)

7. Nashchokina, M.V. Russkie sady: XVIII - pervaya polovina XIX [Russian gardens: XVIII - first half of XIX]. Moscow, ArtRodnik Publ., 2007, 255 p. (In Russ.)

8. Bolotov, A.T. Zamechaniya o prevrashchenii prostykh natural'nykh lesochkov $v$ uveselitel'nye [Notes on the transformation of simple natural woods into entertainment].
In: Ekonomicheskii magazine [Economic store], 1784, Part 20. (In Russ.)

9. Bolotov, A.T. 0 napravlenii starykh sadov [About the direction of old gardens]. In: Ekonomicheskii magazine [Economic store], 1784, Part 12. (In Russ.)

10. Semenov, V.N. Blagoustroistvo gorodov [Improvement of cities]. Moscow, : Printing house. P.P. Ryabushinsky, 1912, 225 p. (In Russ.)

11. Savarenskaya, T.F. Istoriya gradostroitel'nogo iskusstva. Tom 1 Rabovladel'cheskii i feodal'nyi periody [History of urban planning art. Volume 1 Slave-owning and feudal periods ]. Moscow, Arkhitektura-S Publ., 2019, 442 p. (In Russ.)

12. Romanyuk, S.K. Moskva za Sadovym Kol'tsom [Moscow beyond the Garden Ring]. Moscow, AST Publ., 2001,896 p. (In Russ.)

13. Polyakova G.A. Parki Moskvy: ekologiya i floresticheskaya kharakteristika [Parks of Moscow: ecology and floristic characteristics]. Moscow, GEOS Publ., 2000, 406 sp. (In Russ.)

14. Belyaeva E.L, Markina I.A., Moginov R.G. Metodologiya, metodika, opyt rabot po sokhraneniyu dlya sovremennogo ispol'zovaniya parka usad'by Mikhalkovo [Methodology, methodology, experience of conservation work for modern use of the Mikhalkovo estate park]. In: Academia: arkhitektura i stroitel'stvo [Academia: architecture and construction], 2020, no. 1, pp. 78-84; no. 2, pp. 113-120. (In Russ., abstr. In Engl.)

15. Volkova S.D. Sochivko S.V. Park i chelovek. Ocherki i stat'i o roli parkov $v$ zhizni obshchestva [Essays and articles on the role of parks in thelife of society]. St. Petersburg, Zelenaya strela, 2019, $57 \mathrm{p}$.

16. Likhacheva E.A.,Smirnova E.B Ekologicheskie problemy Moskvy za 150let [Ecological problems of Moscow for 150 years], Monograph, D.A. (ed.) Moscow, Poligrafistpb, 1994, 256 p. (In Russ.)

17. Bakutis V.E., Gorokhov V.A., Lunts L.B., Rastorguev 0.S. Inzhenernoe blagoustroistvo gorodskikh territorii [Engineering improvement of urban areas]. Moscow, Stroiizdat Publ., 1979, 237 p. (In Russ.)

18. Bakutis V.E., Gorokhov V.A., Lunts L.B., Rastorguev 0.S. Inzhenernoe blagoustroistvo gorodskikh territorii i naselennykh mest [Engineering improvement of urban areas and populated areas]. Moscow, Stroiizdatpb, 1994, 453 p. (In Russ.)

19. Vladimirov V.V., Davidyants G.N., Rastorguev 0.S., Shafran V.L. Inzhenernaya podgotovka i blagoustroistvo gorodskikh territorii [Engineering preparation and improvement of urban areas]. Moscow, Arkhitektura-S Publ., 2004, 200 p. (In Russ.)

20. Fedosyuk Yu.A. Moskva v kol'tse Sadovykh [Moscow in the ring of Sadovye]. Moscow, Moskovskii rabochii Publ., 1983, 447 p.

21. Belyaeva, E.L. Osobennosti blagoustroistva i ozeleneniya istoricheskikh gorodov.Podkhody i Metodicheskie rekomendatsii [Features of landscaping and gardening of historical cities. Approaches and guidelines],: Monograph. Moscow, Ekon-Inform Publ., 2021, 270 p. (In Russ.) 